\title{
Erratum to: Development of a Flow-Through Microarray based Reverse Transcriptase Multiplex Ligation-Dependent Probe Amplification Assay for the Detection of European Bunyaviruses
}

Lekbira Hasib • Meik Dilcher · Frank Hufert •

Ursula Meyer-König $\cdot$ Manfred Weidmann

Published online: 30 March 2011

(C) Springer Science+Business Media, LLC 2011

Erratum to: Mol Biotechnol

DOI 10.1007/s12033-011-9389-3

In the original publication, there is a typographical error in the title: the correct title is given here. In addition, the surname of the fourth author is incorrectly captured. The correct surname is Meyer-König.

The online version of the original article can be found under doi:10.1007/s12033-011-9389-3.

L. Hasib ( $₫) \cdot$ M. Dilcher $\cdot$ F. Hufert · M. Weidmann Department of Virology, University Medical Center Göttingen, Kreuzbergring 57, 37075 Göttingen, Germany

e-mail: lhasib@gwdg.de

U. Meyer-König

Department of Virology, Institute of Medical Microbiology and Hygiene, University of Freiburg, Hermann-Herder-Str. 11,

79104 Freiburg, Germany 